\title{
Sivil Toplum, Yönetişim ve Kalkınma
}

\author{
Nurten Derici Temel ${ }^{*}$
}

\section{Öz}

Yeni Kurumsal İktisat Okulunun etkisi ile değişime uğrayan neoliberal kalkınma anlayışında yönetişimin önemine sıklıkla vurgu yapılır. Post Washington mutabakatı sonrası kalkınma yazınında kendine giderek daha fazla yer bulan yönetişim kavramı, devlet, piyasa ve sivil toplumun karşılıklı uyum içinde hareket etmesi anlamını taşır. Yönetişim kavramının dayandığı üç sacayağından biri olan sivil toplum bu çalışmanın odak noktasını oluşturmaktadır. Çalışmanın amacı sivil toplumu iktisadi bağlamda analiz etmek ve bilhassa kalkınma açısından üstlendiği rolü değerlendirmektir. Bu doğrultuda çalışmanın literatüre katkısı sivil toplum kalkınma ilişkisine Yeni Kurumsal Iktisat Okulu perspektifinden bakmak ve birer kalkınma kurumu olarak değerlendirilen STK’ların temsil güçlerinde ve strateji geliştirme davranışlarında meydana gelen değişimleri ortaya koymaktır.

Anahtar Kelimeler: Kalkınma Ekonomisi, Post Washington Mutabakatı, Yönetişim, Sivil Toplum, STK’lar.

\section{Civil Society, Governance and Development}

\section{Abstract}

The importance of governance is frequently emphasized in the understanding of neoliberal development, which has been altered by the effect of the New Institutional School of Economics. The concept of governance, which has found itself more and more in the literature of development after the Post Washington agreement, means that the state, market and civil society act in harmony. Civil society, one of the three pillars on which the concept of governance is based, constitutes the focus of this study. The aim of the study is to analyze civil society in an economic context and to evaluate its role especially in terms of development. Accordingly, the contribution of the study to the literature is to look at the relationship between civil society and development from the perspective of the New Institutional School of Economics and to reveal changes in the representational powers and behaviors in strategy development of NGOs, which are considered as development institutions.

Keywords: Development Economics, Post Washington Consensus, Governance, Civil Society, NGO's.

*Arş. Görevlisi | Uludağ Üniversitesi, İktisat Bölümü | nurtenderici@uludag.edu.tr ORCID: 0000-0001-8452-1230 | DOI: 10.36484/liberal.679412

Liberal Düşünce Dergisi, Yıl: 25, Sayı: 97, Kış 2020, ss. 227-248.

Gönderim Tarihi: 23 Ocak 2020 | Kabul Tarihi: 17 Mart 2020 


\section{Giriş}

Sivil toplum, kalkınma tartışmalarında ve politika önerilerinde giderek daha fazla yer alan kilit bir unsurdur. Devlet ya da piyasa odaklı kalkınma modellerinde yaşanan aksaklık ve yetersizlikler sonrası iki model arasında denge arayışına girilmesi sivil toplumun önemli bir oyuncu olarak öne çıkmasına yol açmıştır. Bu süreçte devletin değişen rolü çerçevesinde yükselen yönetişim kavramı bir hayli öneme sahiptir. Devlet, piyasa ve sivil toplumun uyum içinde hareket etmesi şeklinde yorumlanan yönetişim kavramı uluslararası kurumların özellikle de Dünya Bankası'nın üzerinde durduğu ve gelişmekte olan ülkelere telkin ettiği bir kavram olmuştur. Sivil toplumun kurumsal temsilcileri olan Sivil Toplum Kuruluşları (STK), kalkınma sürecinde devlet ve özel sektör ile işbirliğinde yönetişimin önemli bir ayağı olmuş, bir bakıma “Üçüncü Sektör” olarak konumlanmıştır. Böylelikle STK'ların rolleri de değişime uğramıştır. Kalkınma politikalarında yardımcı ve/veya destekleyici olarak konumlanan STK'lar, daha otonom (belirleyici) bir pozisyon almıştır. STK'ların çoğunlukla uluslararası kuruluşlarla ve devletlerle sıkı bir temas içinde olduğu ve rollerinin bununla bağlantılı olarak şekillendiği görülmektedir. Faaliyetlerini araçsal bir fonksiyonla yerine getiren ve bu yönde fonlanan kuruluşlar misyon bakımından farklılaşmışlardır. STK'lardan insani yardımın ötesinde kalkınmanın sürekliliğini sağlayacak programlara katkı sunmaları beklenirken, STK'lar bu rolü henüz bilfiil yerine getirememektedir. Bu sebeple bağımsız aktörler olarak ön plana çıkmaları zaman alan STK'ların güncel durumuna ve gelecekte üstlenecekleri role ilişkin tartışmalar gündeme gelmektedir.

Sivil toplum, anlamı itibariyle politiktir. Yoksulluğun ve dışlanmanın ardındaki güç dengesizliklerinin köklerini barındırmaktadır. Sivil alan, yoksulluğun azaltılması, eşitlik, adalet ve katılım sağlanması gibi sosyal kalkınma hedeflerini ilerletebilecek ya da aksine engelleyebilecek olan iktidar ilişkilerini ve grup çıkarlarını kapsamaktadır. Kalkınma çerçevesinden değerlendirildiğinde yeni bir kalkınma konsepti ya da kalkınma için potansiyel bir araç olarak sivil toplumu ele almak ve kendi koşulları içinde yorumlamak gerekir (Fowler, 2000: 7). Cameron (2000: 627), sivil toplum ile ekonomi arasında daha fazla bağlantı kurulmasına gerek duyulduğunun altını çizerek STK'ların faaliyetlerini alternatif bir ekonomi paradigması olarak analiz etmek gerektiğini belirtmektedir. Yeni Kurumsal İktisat Okulu (YKİ) ile canlanan kalkınma ekonomisi, STK'lar ve ekonomi arasında yapıcı bağların kurulması için iyi bir çerçeve sunmaktadır (Brett, 1993: 273). Bu noktada kalkınma adına bir kavramsallaştırmaya gidilecek olursa sivil toplum, demokratik kalkınmanın ve iyi yönetişi- 
min tesis edilmesinde bütünleyici ve ayrılmaz bir unsur olarak tanımlanabilir (Dagher, 2017: 55). Küresel yönetişimde demokrasi için bir güç odağı olması sebebiyle sivil toplumun potansiyel sinırları ve imkanları üzerinde durmak gereklidir (Scholte, 2002: 281).

Gönüllülük esaslı kuruluşları birer kalkınma kurumu olarak ele almak mümkündür. Sürdürülebilir kalkınma gündeminin, kadınların güçlenmesi, kapsayıcı toplum ve çevre gibi konulara doğru kayması; sivil toplum aktörlerinin rolünü de bu doğrultuda değiştirmiştir (Kontinen ve Millstein, 2017: 71). Bunun yanı sıra insan hakları kültürünün kalkınmanın diğer tüm yönlerinin önüne geçtiği ve küresel olarak büyüdüğü görülmektedir (Tuijl, 2000: 619) Bu kültüre önemli katkılarda bulunan STK'ların yeni dünya düzeni içindeki yeri de giderek genişlemektedir (Malhotra, 2000: 657). Değişen koşullar çerçevesinde STK'ların güçlü ve zayıf yönlerini tartışarak alternatif kalkınma modelleri için STK'ların donanımlarını analiz etmek önemli hale gelmektedir (Commins, 1999: 620).

Sivil toplum, heterojen bir alan olması sebebiyle sosyal bilimlerde pek çok farklı çalışmaya konu olmaktadır. Sivil toplumun ekonomi içindeki yeri ise araştırmalarda giderek daha fazla öne çıkmaktadır. Bu çalışmada sivil toplumun iktisadi analizi üzerinde durulmuş ve özellikle kalkınma kazanımları bakımından üstlendiği rol değerlendirilmiştir. Çalışmanın amacı sivil toplum kalkınma ilişkisini YKİ perspektifinden ele almak ve birer kalkınma kurumu olarak yorumlanan STK'ların temsil güçlerinde meydana gelen değişimleri değerlendirmektir. Bu doğrultuda öncelikle ekonomi ile bağlantısı yönünden sivil toplum kavramı üzerinde kısaca durulmuştur. Kalkınma kazanımlarındaki yetersizlikler ve bu noktada sivil toplumun üstlendiği rol açıklanmaya çalışılmıştır. YKİ ile Kalkınma Ekonomisi arasındaki yakınlaşma ve ana akım iktisadın geleneksel yaklaşımının dışına doğru kaymasıyla beraber STK'ların kalkınmadaki rolü artmıştır. Alternatif bir yorum ve güçlü bir unsur olarak sivil toplumun kalkınma açısından önemi, güncel gelişmeler ve gelecek hedefleri kapsamında tartışılmıştır.

\section{Sivil Toplum ve Kalkınma İlişkisinin Kavramsal Temelleri}

Sivil toplum özellikle Avrupa tarihinde, modern toplumun tamamlayıcı ögelerinden biridir. Avrupa toplumunda bireyin somut varlığı, sivil toplumun ortaya çıkışına zemin oluşturmuştur. Birey kavramı modern öncesi toplumlarda var olan bir kavram değildir ve birey olmadan sivil toplumun ortaya çıkışından bahsetmek mümkün olmamaktadır. Şehirleşme ve serbest piyasanın ortaya çıkışıyla tedricen oluşan birey kavramı beraberinde burjuva kavramını 
getirmiştir (Keyman, 2004:3). Hegel sivil toplumu "Burjuva toplumu" olarak anlamakta, bu doğrultuda sivil toplumu ihtiyaçlar ve öz-çıkarların çatışma alanı olarak görmektedir. Sivil toplumu ahlaki bir beraberlik formu olarak değerlendiren Hegel'e göre, özel çıkar gözetimi nihai olarak başka herkesin ihtiyacının tatminine katkı yapacaktır. Hegel'den önce sivil toplumu bir 'ahlaki varlık' şeklinde düşünen Adam Smith, feodaliteye karşı alternatif bir beraber yaşama formu olarak 'ticari toplum' anlamında bir sivil toplum tanımlaması yapmıştır. Buna bağlı olarak Smith dâhil İskoç Aydınlanması filozoflarının hemen hepsi için, 'Pazar ekonomisi' ahlaki bir sivil düzende vücut bulmuş ve dayanışmanın varlığıyla tarif edilen bir toplumsal kurum olmuştur (Smith'den akt. Sarıbay, 2013:149-150). Marx ise sivil toplumu ekonomik faaliyetin özerk alanı olarak görmüş ve doğuşunu, geç Ortaçağın komünal hareketine bağlamıştır. Marx'ın eserlerinde sivil toplum, kapitalizmle ya da burjuva toplumuyla iç içedir ve sivil toplum kapitalizmin ya da burjuvazinin gelişiminin bir koşulu değil ürünü olarak değerlendirilir (Marx’tan akt. Sar1bay, 2014:171). Burjuvalar, var olan aristokrasiye karşı mücadelede mülkiyet hakları, serbest pazarda dolaşım hakları gibi haklar elde etmişlerdir. Dolayısıyla siyasal olmayan fakat ekonomik hayatı güvence altına alan ve doğrudan ekonomiyle ilişkili olan sivil hakların kazanılmasının, sivil toplumun oluşumunda büyük rol oynadığı söylenebilir (Keyman, 2004: 3).

Sivil toplum modern dünyanın çocuğu olarak görülürken küreselleşme tartışmalarında da merkezi bir yerde konumlanmaktadır. Fakat sivil toplum tarihsel süreç içinde çok farklı biçimlerde yorumlanmıştır. 16. yy. İngiliz siyasi düşüncesinde sivil toplum tanımı ile ima edilen devletin kendisi iken, çağdaş kullanımda sivil toplum kavramsal olarak devlet ile karşıtlığı içermektedir. Modern siyaset kuramının kurucuları ve gelişme dönemi temsilcilerinde sivil toplum, siyasal toplum (geniş anlamiyla devlet) anlamını taşımaktadır. Siyasallık, insan ürünü olma anlamında yapaydır ve doğa durumunun karşıtı olarak konumlanmaktadır. Bu bakımdan sivil toplum da bir “düzenleme"dir ve tümüyle siyasaldır. Fakat Hegel'in devlete, ekonomi ve özel hukuk ilişkilerinden ayrı özel statüye sahip bir alan tanımasıyla ile birlikte sivil toplum ve devlet arasında açık bir ayrım oluşmuştur. Hegel, doğa durumu/sivil toplum (durum) ikiliği yerine devlet/ sivil toplum ikiliğini getirmiştir (Hegel, 1976'dan akt. Savran, 1984:33-34). Bunun yanı sıra Hegel'in 19. yy. sivil toplum nosyonu piyasayı barındırmakta iken, güncel kavramsallaştırmada sivil toplum kar amacı gütmeyen bir sektör olarak nitelendirilmektedir. 1930'lu yıllarda Gramsci sivil toplumu sınıf hegemonyasının onaylandığı bir arena olarak görse de, çağdaş tartışmalarda sivil toplum işleyiş bozucu muhalif taraf olarak tanımlanmaktadır (Scholte, 2002:283). 
Küresel yeni dünya düzeninde sivil toplum; otoriter yönetimi sınırlamak, halkın yetkisini güçlendirmek, pazar güçlerinin toplumsal düzeni parçalayıcı ve bozucu etkilerini azaltmak, siyasal sorumluluğu paylaşarak idarenin niteliğini ve kapsayıcılığını kontrollü biçimde geliştirmek açısından bir araç olarak görülmektedir (Veltmeyer, 2006: 158)

Küreselleşme sürecinin, demokratik yönetişimin, telekomünikasyonun ve ekonomik entegrasyonun yaygınlaşmasıyla beraber, sivil toplumun kapasitesinde çarpıcı gelişmeler olmuş, dolayısıyla tanımlamalar da değişime uğramıştır (Fowler, 2000:10). Dünya Bankası'nın tanımlamasına göre sivil toplum; kamusal yaşamda var olan, üyelerinin ve başkalarının çıkarlarını ve değerlerini dile getiren, etik, kültürel, politik, bilimsel, dini ya da insancıl temellere dayalı olarak kurulan geniş çeşitlilikteki sivil toplum örgütünü ve kar gütmeyen kuruluşu ifade etmektedir (World Bank, 2013). Günümüz şartlarına en yakın sivil toplum kavramı Etzioni'nin (1973) "üçüncü sektör" kavramıdır. Etzioni bu kavramı kullanan ilk isim olsa da literatürde "üçüncü sektör” kavramı daha çok sivil toplum çalışmalarının öncü isimleri olan Salamon ve Anheier'in (1992) çalışması ile ilişkilendirilmektedir. Salamon ve Anheier (1992: 126-127) kendine özgü ve ayrı bir sosyal alan olarak üçüncü sektörün, devletin ve piyasanın dayanılmaz gücüne karşı çeşitli sosyal ve politik hareketlere öncülük yaptığını vurgulamışlardır.

Devletin ve piyasanın sınırları dışında faaliyet gösteren çok çeşitli sosyal kurum vardır. "Kar amacı gütmeyen”, "gönüllü”, “üçüncü” "sivil toplum” ya da "bağımsız” gibi tanımlarla nitelendirilen bu gruptaki her bir kurumun varoluş sebebi farklılık gösterse de bazı ortak noktaları paylaşmaktadırlar. Üniversiteler, hastaneler, sosyal kulüpler, meslek kuruluşları, çevre grupları, aile danışmanları, gündüz bakım merkezleri, spor kulüpleri, iş eğitimi merkezleri, insan hakları kuruluşları gibi pek çoklarının sayılabileceği bu kurumların ortak özellikleri aşağıdaki beş başlık altında toplanabilir (Salamon vd., 1999:3-4):

i. Örgüttürler. Kurumsal bir varlık ve yapıya sahiptirler.

ii. Özeldirler. Kurumsal olarak devletten ayrıdırlar.

iii. Kâr dağıtımı yoktur. Yöneticilere kâr payı verilmez.

iv. Özerktirler. Kendi işlerini kendileri yönetir ve kontrol ederler.

v. Gönüllüdürler. Üyelik yasal olarak gerekli değildir. Üyeler isteğe bağlı biçimde zaman ve para katkısı sunmaktadırlar.

Bu kurumlar dünya genelinde insan ihtiyaçlarına hizmet etmekle kalmayıp aynı zamanda büyük ve gelişen bir ekonomik güç oluşturmaktadırlar. Bu 
yönüyle ekonomik ve sosyal hayata önemli katkıda bulunmaktadırlar (Salamon vd., 1999:32). Sivil toplum anlamı itibariyle STK'ların çok ötesinde bir kavramdır. Fakat kalkınmanın sivil toplumu içine alarak genişleyen gündeminde STK'lar sadece ‘sivil buzdağının görünen yüzü' ve bir başlangıç noktası olarak görülmektedirler (Fowler, 2000:10). Bu yüzden STK'ları sivil toplumun kurumsal temsilcileri olarak nitelendirmek mümkündür. Nitekim kalkınma ajansları, sivil toplum ile verimli ve etkin bir ortaklığı STK'lar aracılığıyla sağlamakta ve STK'lara giderek daha fazla fon kanalize etmektedirler. Yeni ve büyük bütçeli finansman kaynaklarına ulaşımın kolaylaşmasıyla 1990'lı yıllardan itibaren sivil toplum dünya genelinde yükselişini sürdürmüştür.

\section{Kalkınma Anlayışındaki Değişim ve Yönetişim}

1950'lerden bu yana kalkınma ekonomisi yazınının, kültürel ve toplumsal düzenlemelerin kuramsallaştırılması konusunda farkındalığa sahip olduğu ve ana akım iktisattan farklı konumlandığı söylenebilir. Zaman içinde geleneksel olarak iktisat dışı görülen konuların giderek daha fazla iktisat disiplini içinde yer almaya başlamasıyla kalkınma ekonomisi bu eğilimden en çok etkilenen alanlardan biri olmuştur (Bardhan, 1993:139).

1970'lere kadar yoksulluğu önlemeye yönelik programlarda merkezi sorumluluk için devlet işaret edilmiş, 1980 sonrası ise Neoliberal düşüncenin yaygınlaşmasıyla beraber yetersiz iktisadi gelişmenin temel nedeni olarak yaygın ve aşırı devlet müdahalesi gösterilmiştir. Neoliberal düşüncenin ürünü olan ve Chicago Okulu ekonomisti John Williamson tarafından ortaya atılan Washington Mutabakatı üç önemli uluslararası kurumun (IMF, Dünya Bankası ve WTO) kabul ettiği ve önerdiği Neoliberal politikalardan oluşmaktadır. Bu mutabakata göre devlet, sorunların çözümü değil bizatihi sorunun kendisidir ve başarılı bir kalkınma politikası için öncelik serbest piyasa düzenidir. Ancak kalkınma ekonomisi 1990’lara gelindiğinde krize girmiş; Washington Mutabakatının sunduğu öneriler kalkınma sorunlarına cevap vermekte yetersiz kalmıştır. Bu durum eleştirileri ciddi biçimde artırmıştır. Washington Mutabakatı döneminde devletin geri çekilmesini gerektiren kuram çerçevesinde tam rekabetçi piyasalar gelişmiş ancak kalkınma ekonomisi gerilemiştir (Wayenberge Van, 2013:318). Finansal krizlerin ve dünya çapında birçok ülkede yaşanan sosyal sorunların ardından mutabakatın en güçlü savunucularından dahi sert tepkiler gelmeye başlamıştır (Salamon vd., 1999:4). Dönemin Dünya Bankası baş ekonomisti olan Stiglitz’e göre (2013:286), Washington Mutabakatı sosyal ve politik boyutları göz ardı eden bir politikadır. Böyle bir politika salt kötü bir sosyal politika değil aynı 
zamanda kötü bir iktisat politikasıdır. Ticarette liberalizasyon, özelleştirme ve esnek işgücü piyasası reformları gibi neoliberal politikalar küresel yoksulluğun ve eşitsizliğin büyümesiyle sonuçlanmıştır. Küresel ölçekte gelişen dünya insani yoksulluk sorunundan kopmuştur (Pearce, 2000:19).

Gerek devlet eliyle yürütülen kalkınma politikalarının gerekse de Neo Klasik iktisadın gelişmekte olan ülkelere tavsiye ettiği piyasa odaklı çözümlerin, kalkınma üzerinde etkileyici sonuçlar üretememesi alternatif kalkınma yaklaşımlarının geliştirilmesine yol açmıştır. Kalkınma ekonomisi kendisini eleştirel bir biçimde sorgulamaya başlamış, yeni bir kavramsal çatı arayışına girmiştir. Böylelikle kurumsal vurgu ile güçlü bir yankı bulmuş̧tur. Bu süreçte YKİ'nin kurumları iktisadi analizin merkezine alan yaklaşımı kalkınmaya yeni bir perspektif sunmuştur.

YKİ'nin görüşleri üzerine Washington Mutabakatı yerini yönetişim ve kurumlara daha fazla önem veren Post Washington Mutabakata bırakmıştır. Artık başarılı bir kalkınma için gerekli olanın, iyi işleyen kamu sektörünün ve özel sektörün işbirliği içinde hareket etmesi olduğu görüşü kabul edilmektedir (Wayenberge Van, 2013:318). Neoliberal kalkınma anlayışı ekonomik kalkınmaya yön vermeye devam etmekte fakat bunu 1980'lerin liberal görüşünden oldukça farklılaşarak gerçekleştirmektedir. Geçmişte devleti küçültmeye çalışırken kurumsal başarısızlıkların piyasaların işleyişini olumsuz etkilediği görülmüş, kaliteli kurumlar ve iyi yönetişim önerileri yükselmeye başlamıştır (Aysan, 2019:13). İlkinden farklı olarak Post-Washington Mutabakatında devlete sınırlı da olsa bir müdahale alanı bırakılmış, yönetimde çoğulculuğa işaret edilerek yönetişim kavramı ön plana çıkarılmıştır. Neoliberal düşüncenin hâkim olduğu Dünya Bankası, Uluslararası Para Fonu (IMF), Birleşmiş Milletler Kalkınma Programı (UNDP) gibi uluslararası kuruluşların yönetişim kavramına önem vermeye başlaması değişimin önünü açmış (Aysan, 2019:2), kavramın yükselişinde belirleyici rol oynamıştır (Bayramoğlu, 2005:28).

Uzun vadeli kalkınma anlayışının daima yeni manevralara açık olduğu görülmektedir (Edwards vd., 1999:126) Günümüz kalkınma yaklaşımlarında yönetişime ve çoğulculuğa (pluralism) yapılan vurgu bu bakımdan önem arz etmektedir. Ve yeni bir rotanın çizildiğinin göstergesidir. 1980'lerden itibaren kalkınmanın etkin bir yönetişim olmadan başarısız olduğu görüşü yaygınlaşmaya başlamıştır. Dünya Bankası yönetişimi devlet-piyasa-sivil toplum üçlüsünü bir arada tutan tutkal olarak görmektedir (Levent, 2016:28). 1997 yılında Birleşmiş Milletler Kalkınma Programının (UNDP) hazırladığı 'UNDP Ve Yönetişim: Deneyimler ve Öğrenilen Dersler' raporunda da başarılı 
kalkınmanın sağlanmasında yönetişimin merkeziliği üzerinde durulmuştur (Lyon,2000:87).

Yönetişimin genel anlamda birbiriyle ilişkili ve iç içe geçmiş anlamlara sahip pek çok tanımı vardır. Yönetişim, birbirine bağlı faaliyetlerin herhangi bir koordinasyon biçimi olarak anlaşılabilir. İkinci bir tanımlamaya göre ise yönetişimin daha kısıtlı bir anlamı vardır. Buna göre yönetişim, heterarşik bir yapı ya da öz örgütlenme olarak ifade edilebilir. Bu tanım, kendi kendini organize eden kişilerarası ağları, müzakere edilen organizasyonlar arası koordinasyonu ve bağlam aracılığıyla sağlanan sistemler arası yönlendirmeyi içermektedir (Jessop, 1998:29) YKİnin önde gelen isimlerinden Williamson'a göre yönetişim, alternatif organizasyon araçlarının etkinliğinin değerlendirilmesine olanak sağlayan bir uygulamadır. Buna göre kurumlar, yönetişim mekanizmalarıdır ve iyi düzen, iyi yönetişim mekanizmaları vasıtasıyla sağlanmaktadır (Williamson, 1996:11). Avustralya Uluslararası Kalkınma Kurumu tarafından hazırlanan "Daha İyi Bir Gelecek İçin Daha İyi Yardım” (Better Aid for a Better Future) isimli raporda iyi yönetişim, "Bir ülkenin sosyal ve ekonomik kaynaklarının açık, şeffaf, hesap verebilir ve adil şekilde etkin yönetimi” olarak tanımlanmıştır. Yönetişimin pek çok tanımı olsa da genel olarak bir ülkedeki sivil, siyasi ekonomik yaşama katılım, hukukun üstünlüğü, ifade özgürlüğü, bağımsız medya ve insan hakları gibi ilkeler yönetişim tanımlarının ortak paydasını oluşturmaktadır (Lyon,2000:87). Çok çeşitli boyutları olan bu ilkeleri yerine getirmek ve gelişmiş bir yönetişimi tam anlamıyla tesis etmek tahmin edileceği üzere oldukça güçtür. Dolayısıyla Rodrik'e göre iyi yönetişim, kalkınmanın kendisidir (Rodrik, 2008:17).

İyi yönetişimi hem bir araç hem de bir amaç olarak yorumlamak mümkündür. İyi yönetişim, kalkınmanın geniş bir şekilde yorumlanmış temel amacı aynı zamanda da daha iyi politika oluşturma ve daha iyi ekonomik sonuçlar elde etme aracıdır (Rodrik, 2008:18) Washington Konsensüsünden sonra ortaya çıkan bu kavrayışa göre başarılı politika reformunun temeli yönetişim reformudur. Kalıcı bir değişim için gerekli olan, politikanın başarısını belirleyen iktisadi aktörlerin davranışları üzerinde bir etkiye sahip olmaktır. Bu doğrultuda kapsamlı yönetişim reformlarına odaklanan yeni bir kalkınma gündemi oluşmuştur (Rodrik, 2008:17).

\section{Bir Yönetişim Mekanizması Olarak STK’lar}

Devletin iyi yönetişim çerçevesinde müdahaleci değil koordine eden bir rol üstlenmesiyle beraber geleneksel refah ekonomisi önermeleri rafa kaldırılmış böylece iktisadi kalkınmada STK'lar ve kolektif etkinlikler kendilerine 
önemli bir yer bulmuşlardır (Wayenberge Van, 2013:318). Ekonomik kalkınmayı teşvik etmek ve ortak bir yaşam alanı oluşturmak için hareket eden bu tür organizasyonlar itici bir güç olarak görülmeye başlanmıştır. Devletin, özel sektörün ve sivil toplumun yoksullukla mücadele etme konusunda birbirini tamamlayıcı ilişkisi olduğu artık genel kabul görmektedir. Çağdaş yönetişim çok katmanlı bir yapıya sahiptir. Korten (2009:100)'e göre gerçek refah ekonomisi, özel sermaye, devlet ve sivil toplumun her birinin tam bir denge içinde kümelenmesidir.

Sivil toplum yönetişimin önemli bir sacayağıdır. Sivil toplumun kurumsal temsilcileri olan ve çeşitli hedef kitlelerle ilgilenen STK'lar ise birer yönetişim mekanizması olarak değerlendirilebilir. Williamson, kurumların ve organizasyonların "sınırlı rasyonalite” ile ilişkilendirilerek düşünülmesi gerektiğini vurgulamaktadır. İşlem maliyetleri ekonomisine göre bireyler ve firmalar gibi ekonomik ajanlar sınırlı rasyonaliteye sahiptirler. Davranış rasyoneldir fakat sınırlı bir biçimde tasarlanmıştır. (Williamson, 1985:30). Williamson'a göre ekonomik ajanlar Neoklasik ekonomi modellerine uymayan şekillerde davranma potansiyeline sahiptirler. Bu bağlamda STK'ların davranış kalıpları “sınırlı rasyonalite” çerçevesinde ele alınmalıdır. Sivil toplumu sınırlı rasyonalite çerçevesinde iki faklı açıdan değerlendirmek mümkündür. Öncelikle piyasa ya da devletin dışında konumlanan sivil alanda diğerkamlık ve karşılıklı ödün ilişkileri hâkimdir. Ancak çıkarcı (self-interested) ve hatta fırsatçı motivasyon - başka platformlarda sergilendiğinden farklı olsa da - gönüllü kuruluşlarda kendini göstermektedir (Brett, 1993:275). Bireylerin kendi çıkarlarını ve değerlerini ifade etmelerinin fiyatı düşük ise bu değerler yaptıkları seçimlerde büyük rol oynayacaktır. Fakat bireyin kendi ideolojisini, normlarını veya seçimlerini ifade etmesinin bedeli olağanüstü yüksek ise bu değerler davranışlarda çok daha az etkilidir (Nelson ve Silberberg, 1987'den akt. North, 2002:33).

Diğer taraftan STK'ların faaliyetleri, geçiş ajanları olarak nasıl hareket ettikleri, işlem maliyetlerini nasıl yönettikleri, tüm iç ve dış paydaşlar için belirsizliğin maliyetlerini nasıl azalttıkları ve yeniden nasıl dağıttıkları bakımlarından değerlendirilebilir (Cameron, 2000:629-635). Sivil toplum; gönüllü derneklerin toplumsal hayatın bir ya da birden çok yönünü yöneten kuralları bilinçli olarak şekillendirmeye çalıştıkları bir alandır. Bu alandaki "kurallar", belirli politikaları, genel normları ve derin toplumsal yapıları kapsamaktadır. Ekonomik ajanlar olarak belirli davranış formlarına sahip STK'lar, toplumsal hayatı yönlendiren norm ve yapıların oluşumunda etkilidirler. Sivil alana ilişkin kurallar ile belirsizliklerin maliyetini azaltmada etkin bir rol oynayabilirler. STK'lar yürüttükleri faaliyetler ile resmi birtakım direktifleri 
(mevzuat gibi) hedefleyebileceği gibi, gayri resmi yapıları (toplumsal cinsiyet rolleri gibi) veya bir bütün olarak toplumsal düzeni hedefleyebilirler (Scholte, 2002:283).

Scholte (2002:281), sivil toplumun sosyal hayatı düzenleyici yönünün "küresel yönetişim" bakımından önemine dikkat çekmiştir. Yerel, bölgesel ve küresel süreçlerin ulusal düzenlemeler ile iç içe geçtiği yeni dünya düzeninde "küresel yönetişim" kavramı önem kazanmaktadır. Sivil toplum, ilgili düzenleyici kurumların kamusal hesap verebilirliğini artırarak küresel yönetişimde demokrasiyi teşvik edici rol oynamaktadır. Sivil toplum ve düzenleyici mekanizmalar arasındaki angajman, vatandaşların yönetişime olan saygısını arttırarak potansiyel kazanımların önünü açmaktadır. (Scholte, 2002: 288-295). STK'ların yönetişimdeki merkezi konumu söz konusu toplumsal denetim ve katılımcı demokrasi anlamındaki ilerici toplumsal işlevlerinden kaynaklanmaktadır (Yüksel, 2014:165).

Toplumsal örgütlenmenin yoğun olmadığı, sivil toplum örgütlerinin ve ağlarının temel işlevlerini yerine getiremediği bir toplumda yönetişimin uygulanabilirliği tehlikeye düşmektedir (Sobac1, 2007: 323). "İyi yönetişim”, sadece verimlilik ve düzenin sağlanması değil bunun yanı sıra toplumsal katılım ve kamu hesap verebilirliğine ulaşımın da temin edilmesi demektir (Scholte, 2002: 283). Bu nedenle STK'lar gibi organizasyonlar aracıllğıyla etkin hesap verebilirlik mekanizmalarının kurulması, sosyal olarak yararlı faaliyetlerin gerçekleştirilmesini sağlamaktadır (Brett, 1993:275). “Üçüncü sektör" olarak sivil toplumun özel sektör ve devlet işbirliği içinde yer alması Şekil l'de görüldüğü üzere küresel yönetişim ve değer yaratma sürecinde büyük önem taşımaktadır.

Şekil 1: Küresel Yönetişim ve Değer Yaratımında Sivil Toplum Kuruluşlarının Önemi

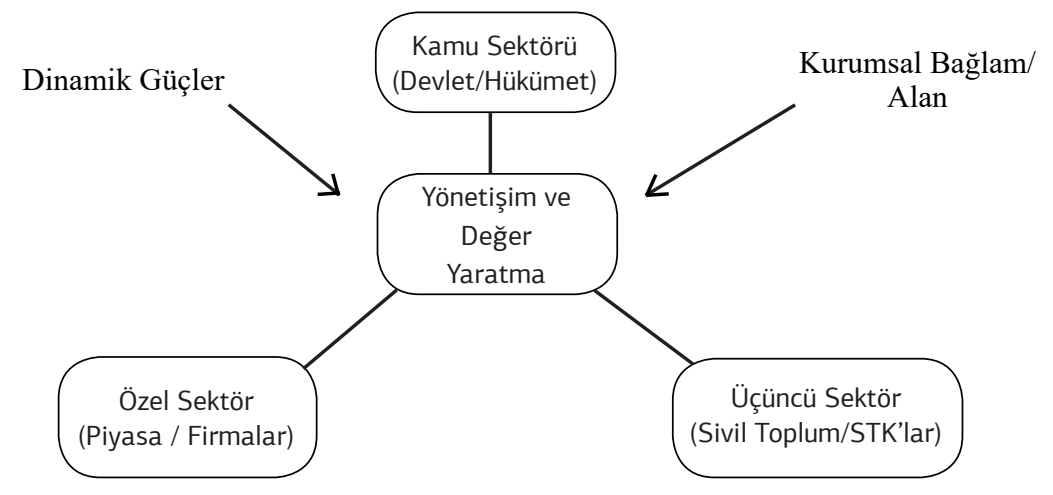

Kaynak: Teegen, Hildy; Doh, P. Jonathan ve Vachani, Sushil (2004: 463-483). 
Etkin ve hesap verebilir bir yönetim, iyi yönetişim ve sürdürülebilir kalkınma için devletin, piyasanın ve sivil toplumun yakın ilişki içinde çalışması gerekmektedir. Kalkınma programlarının; devletin, özel sektörün ve sivil toplumun işbirliği ile yürütülmesi önerilmektedir. Böylelikle STK'ların sunduğu katkı ile toplumsal program uygulamaları için tüm kesimlerden sağlanan yarar maksimize edilebilecektir (Psacharopoulas ve Nguyen, 1997:viii).

\section{Etkin Kalkınma için STK'ların Rolü}

Sivil toplumun iktisadi hayatta ve etkin kalkınmadaki rolü hayli önemlidir. Gelişmekte olan ülkelerde var olan beşeri sermaye, doğal kaynaklar ve finansal kaynakların etkin kullanımına olan ihtiyaç; STK'ların faaliyetlerini bu kaynakların etkin kullanılması yönünde teşvik etmektedir (Psacharopoulas- Nguyen, 1997:49). STK'ların etkin kalkınmaya katkısını mikro ve makro açıdan değerlendirmek mümkündür. STK'lar mikro düzeyde gelir getirici faaliyetler organize etmekte ve doğrudan bir destek sağlamaktadırlar. Makroekonomik strateji belirlenmesi noktasında ise büyüyen yoksulluk ve buna bağlı oluşan güvensizlik ortamında piyasaların ve devletin yetersiz kalması STK'ları aktif bir taraf konumuna itmektedir (Cameron, 2000:627). STK'lar demokratik değişimin etkili oyuncularıdır ve toplumsal olarak kapsayıcı, eşitlikçi, katılımcı ve sürdürülebilir bir kalkınma biçiminin tesisinde önemli rol oynamaktadırlar (Veltmeyer, 2006:160). STK'lar, yüksek demokratik katılım seviyesinin bir göstergesi olan toplumsal bağların ve ağların güçlendirilmesine katkıda bulunabilecek kalkınma aktörleri olarak görülmekte (Lewis ve Kanji, 2009:61) ve birçok yönden kalkınma etkinliği ile ilişkilendirilmektedirler.

Etkin kalkınmada STK'lar üç bakımdan önemli rol oynarlar (TRIALOG, 2013:1):

-Bağışta bulunanların ve diğer kalkınma aktörlerinin hareketlerini izlerler ve yolsuzluklara karşı bekçi (watchdog) rolü oynarlar

-Çok paydaşlı tartışmalarda yer alarak kalkınma etkinliğinin küresel gündemini şekillendirirler

-Eylemlerini ve nasıl hareket edeceklerini uluslararası alanda kabul edilmiş kalkınma etkinliği ilkelerine göre belirleyerek kalkınma etkinliğini arttırmaya yardımcı olurlar.

Etkin kalkınmada sivil toplumun artan önemi 1980'lerde neoliberal düşünce öncülüğünde pek çok devletin kendini geri çekmesiyle ilişkilendirilebilir. Bu dönemde kurulan STK'ların sayısında belirgin bir artış yaşanmıştır. 
Bugün az gelişmiş veya gelişmekte olan ülkelerde faaliyet gösteren STK'ların büyük çoğunluğunun bu dönemde kurulduğu düşünülmektedir (Veltmeyer, 2006:159). Bilhassa 1980'lerin sonları ve 1990'ların başlarında STK'lar, uluslararası yardımların dağıtımında ve kalkınma programlarında etkin ve verimli kuruluşlar olarak yer almışlardır. Soğuk Savaşın sona ermesiyle sivil toplumun devlet karşıtlığını barındıran eski kavramsal yapısı değişime uğramış ve uluslararası kalkınmada ön plana çıkmaya başlamıştır. Sivil toplum, Sovyetler Birliği'nin dağılmasıyla bağlantılı olarak yeni bir önem kazanmış ve kalkınma gündeminde yeni bir örgütlenme biçimi olarak kilit bir unsur halini almıştır (Fowler, 2000:3).

Sivil toplumun, kalkınmaya ilişkin önemli bir tema olarak hızlı bir gelişme yakalaması, 1995'te Kopenhag'da düzenlenen Birleşmiş Milletler (BM) Dünya Sosyal Zirvesi’yle olmuştur. Kalkınma denildiğinde 70 yılı aşkın geçmişiyle en büyük küresel ortak olan Dünya Bankası'nın iyi yönetişim çalışmaları bağlamında hükümet politikalarının STK'ların gücünü nasıl etkilediği üzerine odaklanması önemli bir gelişme olarak karşımıza çıkmaktadır. Dünya Bankası'nın bünyesinde STK'larla ilişkileri güçlendirmek ve politika diyaloğu için uygun ortamı sağlamak adına merkezi bir STK birimi kurulmuştur. Bunun yanı sıra Dünya Bankası, üye devletleri sivil toplumla işbirliği içinde çalışmaya davet etmekle kalmayıp STK'ların projelerine doğrudan kaynak desteği sağlamıştır. Dünya Bankası verilerine göre 1990 yılı için yürürlükte olan projelere STK'ların katılımı \%12 oranındayken, 1998 yılında STK'ların aktif projeler içindeki yeri \%38'e yükselmiştir. Bu kuruluşların çoğu gelişmekte olan ülkelerin STK'larıdır (World Bank, 1998:3-5). Kalkınma, kalkınma yardımları ve STK'lar arasındaki ilişki uzun süredir kabul görmektedir. Ancak neoliberal çağda uluslararası ekonomik liberalizasyon ile beraber kalkınma sadece bir 'iş' haline dönüşmüş ve söz konusu ilişki de değişime uğramıştır. "Sürdürülebilir kalkınma (Sustainable Development)" ya da "Kendiliğinden kalkınma (Self Development)" gibi tanımlamaların kullanımı artmış, kalkınma birtakım vasıflar eşliğinde takdim edilmeye başlanmıştır. Bu süreç dikkat çekici bir biçimde STK'ları da tahrip etmiştir. STK'lar serbest piyasa modeli içinde rekabete teşvik edilen kurumlar olarak yer almaya başlamışlardır. Rekabetçi bu model içinde STK'lar kurumsal yapıları bakımından hiçbir zaman olmadıkları kadar benzer hale gelmişlerdir. Öyle ki birçok gündem, işlev ve değer birleştirilmiştir. Bu ise STK'ların faaliyet alanlarının sınırını çizmiş ve standartlaşmalarına yol açmıştır. Pearce (2000:20) bu süreçte STK'ların adeta devletlerin insani acılara karşı ilgisizliğini ve ataletini örten birer 'incir yaprağı’ görevi gördüğünü iddia ederek bu durumu eleştirmiştir. 
Yapılan çalışmalar bu eleştirinin çok da yersiz olmadığını gösterir niteliktedir. STK'ların toplumsal kalkınma üzerindeki işlevsel etkisinin iddia edilenden çok daha az olduğu görülmüştür. Devletin, eğitim, sağllk gibi alanlardaki rolünü azaltma politikası doğrultusunda STK'lar ve benzeri kuruluşlar devletin bir alternatifi şeklinde görülmüş ve fonlanmışlardır. Ancak artan yardımların yoksulluğun azaltılması veya kalkınma bakımından istenilen sonuçlar vermediği ve kaynakların etkin kullanımının ciddi bir sorun teşkil ettiği görülmüştür. Uzun vadeli kalkınma için kullanılabilir fonların kısıtlı olması ve bu fonların artan oranda insani acil durum yardımlarına aktarılması sebebiyle STK'ların kalkınma üzerindeki etkileri oldukça sınırlı kalmıştır. Bu sorunla mücadeleye yönelik olarak sivil toplum çalışmalarının, yerel programlardan ulusal hükümetlerle olan ilişkilere ve çok uluslu kuruluşlara kadar her seviyede değerlendirilmesi gündeme gelmiştir. Geleneksel roller ve değişen bölgesel - küresel şartlar altında STK'ların geleceğine yönelik çok önemli bir konu öne çımıştır. Etkin bir kalkınma aktörü olmaları için STK'ların başkalaşması gerekmektedir. Commins'in (1999:621) tabiriyle STK'lar ya 'küresel çorba mutfağında kepçe' olma rolünü kabul edecek ve yalnızca insani yardım dağıtan kuruluşlar olacaklardır ya da zor olanı başarma yoluna gideceklerdir. Commins (1999), 1990'ların sonlarına doğru uluslararası STK'ların kendilerine ilk rolü seçtiğini ileri sürerek bu gelişmenin olumsuz sonuçlarına işaret etmiştir. İkinci yolun tercih edilmesi ile kastedilen, STK'ların sadece yardım götüren kuruluşlar değil sorumluklarının ve toplumdaki rollerinin farkında olan toplumsal gözlemciler olarak hareket etmeleridir. Buna göre STK'ların politika içindeki kurumsal rollerini yeniden tanımlamaları gerekmektedir. Sosyal adaletin sağlanması, hesap verebilirliğin güçlenmesi ve yoksullukla sürdürülebilir biçimde mücadele edilmesine yönelik programlarda STK'ların aktif olarak yer almaları ve ilerici bir fonksiyon üstlenmeleri beklenmektedir (Malhotra, 2000:660-663). STK'lar kendi esas rolleri olan toplumsal değişimin ve pazar dışı değerlerin destekçisi olmaya, insan haklarına ve demokratik süreçlere saygıya ve tüm bunları ekonomiye, sosyal politikaya ve çevreye dair kararlar alırken asıl önem teşkil eden hususlar olarak dikkate almaya davet edilmektedirler (Edwards vd., 1999:134).

Sivil toplumun büyümesini ve güçlenmesini, demokrasinin ve otonom kalkınma kapasitesinin canlanması olarak gören görüşe göre demokratik canlanma sürecinde STK'lar katılımcı ve kalkınmada öncü kurumlardır (Veltmeyer, 2006:159). Küreselleşmenin getirdiği bir durum olarak, insan haklarının evrenselliği ve sivil, ekonomik, sosyal ve kültürel hakların bölünmezliği tartışmalarının kalkınma söyleminin içine giderek daha fazla girmesi sivil toplumun rolünü arttırmıştır. İnsan haklarının evrenselliği çerçevesi; iyi 
kalkınma için gerekli olan politik, ekonomik, sosyal ve kültürel standartları içermekte ve dünya genelinde uygulanabilirlik için tüm devletlere eş yükümlülük yüklenmesi gerekliliğini ortaya koymaktadır. Toplumdaki bireyler, kendi kişisel yaşamlarındaki gelişmeyi tanımlayabilmek için yapısal bir çerçeveye ve birbiriyle ilişkilendirilebilecek standartlardan oluşan bir dile ihtiyaç duymaktadırlar. Genel olarak insan hakları dilinin, STK'ların misyonlarının ve küresel STK ilişkilerinin kalkınmada merkezi hale gelmesi bu ihtiyaçla ilişkilendirilmektedir (Tuijl, 2000:619-621).

Bu kuruluşlar topluluklar arası diyalog kurarak kalkınma koalisyonlarını oluşturma ve kalkınmanın planlamasına halkın katılımını sağlama noktasında kritik öneme sahiptirler. Ancak politik çatışma alanlarının ve karmaşık acil durumların içindeyken üstlenilen roller değişime uğramakta ve STK'lar geleneksel rol ile ilerici rol arasında bir ikilem yaşamaktadırlar. Küresel süreçler yüksek düzeyde güvensizlik ürettikçe, STK dünyasının yaşadığı ikilemler daha belirgin bir şekil almaktadır (Edwards vd., 1999:125-126). Bu ikilem göz önüne alındığında STK'lar için melez ve stratejik bir seçenekten bahsetmek gerekmektedir. Buna göre bir taraftan temel ihtiyaçları karşılamak üzere yardım ve kalkınma faaliyetleri yürütülecek diğer taraftan ise geleceğe dönük ekonomik ve sosyal kalkınma olasılığını güçlendirecek fiziki, beşeri ve sosyal sermayenin yaratılmasında sorumluluk alınacaktır (Edwards vd., 1999:128). Özellikle hizmetlerin dağıtımı konusunda tamamlayıcı rolü olan STK'lar kısa dönemli programlarda etkin bir unsur olarak yer alarak insani yardıma katkı sunma potansiyeline sahiptirler. Uzun dönemde ise sosyal sermayeyi güçlendirme kapasitesine sahip olan bu kuruluşlar küresel kalkınmayı olumlu etkileyebilirler. Bu sebeple halkı tabanda örgütleme gücü dikkate alınarak STK'ların mevcut programlarının sonuçları değerlendirilmeli, gelecek tercihleri ile ilgili olarak da potansiyeli yüksek çalışmalar üzerinde odaklanılması önerilmektedir. Ancak STK'ların uzun dönemli stratejik plan geliştirmeleri çok kolay olmamaktadır. Halkın eğitim düzeyini geliştirmeye, şeffaflığı arttırmaya, hesap verebilirliği arttırmaya yönelik çeşitli platformlar oluşturmaları zaman almaktadır. STK'ların küresel ilişkileri düzenleyen kurallarını ve demokratik meşruluğunu kabul ettirip arttırabilmeleri zamanla mümkün hale gelmektedir (Scholte, 2002:300). Lewis ve Kanji'nin (2009:15) Korten'den (1990) uyarlayarak yorumladığı aşağıda yer verilen Tablo 1'de STK'ların tarihsel süreçte strateji geliştirme davranışları dört farklı dönem itibariyle gösterilmektedir. Buna göre birçok STK kurulduğu andan itibaren sivil alanda deneyim kazanmakta ve strateji geliştirme davranışları değişmektedir. STK'lar ilk kuruldukları dönemde (1.Kuşak) daha acil problemlere çözüm arayan ve faaliyet alanları oldukça dar kuruluşlardır. Zamanla daha 
uzun dönemli ve işbirlikli (kamusal ya da özel kurumlarla) projeleri hayata geçirmeleri, faaliyet alanını birey/aile kapsamından ulusal/küresel ölçeğe kadar genişletmeleri mümkündür. Bu potansiyele sahip STK’lar kuşak atlayabilir ve kalkınmanın planlamasında önemli roller üstlenebilirler. STK'lar daha geniş kitleler tarafından kabul görmeye ve desteklenmeye başladıkça hareket kabiliyetleri artmakta, geleneksel roller geri plana atılmakta ve daha dinamik bir yapıya sahip olup etkin kalkınmayı güçlendirmektedirler.

Tablo 1: Sivil Toplum Kuruluşlarının Kuşaklararası Strateji Geliştirme Davranışları

\begin{tabular}{|c|c|c|c|c|}
\hline & 1.Kuşak & 2.Kuşak & 3.Kuşak & 4.Kuşak \\
\hline Problem Tanımı: & Kıtlık & Yerel Atalet & $\begin{array}{c}\text { Kurumsal ve } \\
\text { Politika Kısıtlamaları }\end{array}$ & $\begin{array}{c}\text { Yetersiz } \\
\text { Seferberlik } \\
\text { Vizyonu }\end{array}$ \\
\hline Zaman Aralığı: & Acil & Proje Ömrü & $10-20$ yıl & $\begin{array}{r}\text { (Süresiz) } \\
\text { Gelecek }\end{array}$ \\
\hline $\begin{array}{l}\text { Faaliyet Kapsamı: } \\
\text { (alanı) }\end{array}$ & $\begin{array}{c}\text { Birey } \\
\text { ya da Aile }\end{array}$ & $\begin{array}{l}\text { Mahalle } \\
\text { ya da Köy }\end{array}$ & $\begin{array}{c}\text { Bölge } \\
\text { ya da Millet }\end{array}$ & $\begin{array}{c}\text { Ulusal } \\
\text { ya da Küresel }\end{array}$ \\
\hline $\begin{array}{l}\text { Ana Unsurlar: } \\
\text { (aktörler) }\end{array}$ & STK & $\begin{array}{c}\text { Topluluk } \\
\text { Destekli STK }\end{array}$ & $\begin{array}{l}\text { İlgili Tüm Kamusal } \\
\text { ve Özel Kurumlar }\end{array}$ & $\begin{array}{c}\text { Genel } \\
\text { Hatlarıyla } \\
\text { Tanımlanmış } \\
\text { Halk ve } \\
\text { Organizasyon } \\
\text { Ağları } \\
\end{array}$ \\
\hline STK'nın rolü: & Yapıp eden & Harekete Geçiren & Hızlandıran & $\begin{array}{l}\text { Eylemci / } \\
\text { Eğitimci }\end{array}$ \\
\hline Strateji: & $\begin{array}{l}\text { Yardım } \\
\text { ve Refah }\end{array}$ & $\begin{array}{l}\text { Toplumsal } \\
\text { Gelişme }\end{array}$ & $\begin{array}{l}\text { Sürdürülebilir } \\
\text { Sistemler Geliştirme }\end{array}$ & $\begin{array}{c}\text { Halk } \\
\text { Hareketleri }\end{array}$ \\
\hline
\end{tabular}

Kaynak: David Lewis ve Nazneen Kanji, (2009:15)

Dünya genelindeki sayısız gelişmenin bir sonucu olarak kalkınma camiası artık yardımların etkinliği hakkında değil kalkınmanın etkinliği hakkında konuşmaktadır. STK'ların bu değişimdeki rolü, yoksulluğu azaltma, insan hakları, katılımcı demokrasi, sosyal ve çevresel adalet, sürdürülebilirlik ve cinsiyet eşitliği gibi kalkınmayı etkileyen faktörlere odaklanmasından kaynaklanmaktadır. STK'ların etkin kalkınmadaki fonksiyonunun değişimi pek çok platformda kendine yer bulmakta ve tartışılmaktadır. Kalkınma işbirliğinin ve yardım dağıtımlarının modernize edilmesi ve genişletilmesi yönünde süreklilik arz eden girişimler söz konusudur. Bu girişimler özellikle uluslararası kurum ve kuruluşların önderliğinde yürümektedir. Politika gündemini yardım etkinliğinden kalkınma etkinliğine doğru genişletme amacı güden Amerika Birleşik Devletleri merkezli İyi Yardım (BetterAid) Platformu, BM bünyesindeki Kalkınma İşbirliği Forumu (DCF), Dünya Bankası bünyesindeki Sivil Toplum 
Politika Forumu (CSPF), Avrupa Yardımlaşma ve Kalkınma STK'ları Konfederasyonu (CONCORD) ve uluslararası düzeyde pek çok STK'nın üye olduğu bir birlik olan Sivil Toplum Örgütleri ve Eylemcileri Küresel Birliği'nin (CIVICUS) gerçekleştirdiği toplantılar önemli örnekler olarak gösterilebilir.

STK'ların uluslararası en önemli ortaklarından Dünya Bankası sivil toplumu, Sivil Toplum Fonu ya da Kalkınma Pazarı gibi mekanizmalar yoluyla geliştirme çabası içindedir. IMF ve Dünya Bankası Grubunun bahar döneminde ve yıllık olarak yaptıkları CSPF toplantıları, STK'lar için gerek söz konusu kurumların temsilcileri ile gerekse de hükümet heyetleri ve diğer paydaşlarla fikir alışverişinde bulunmaları için açık bir saha oluşturmaktadır (World Bank, 2017). Diğer taraftan Birleşmiş Milletler bünyesinde 2000 yılında üzerinde anlaşmaya varılan ve bağışçıları sekiz kalkınma hedefi altında birleştiren Birleşmiş Milletler Binyıl Kalkınma Hedefleri ${ }^{11}$ ilk küresel çaba olarak dikkat çekicidir (TRIALOG, 2013:1-2). Bu hedeflerin uygulanma sürecinde bağış yapan ve yardımlardan faydalanan kesimlerin koordinasyonu ve uyumlaştırılması için uluslararası kalkınma işbirliği güçlendirilmeye çalışılmıştır. Koordinasyon eksiklikleri, aşırı iddialı hedefler, gerçekçi olmayan zaman ve bütçe kısıtlamaları, siyasi kişisel çıkarlar çoğu zaman yardımların istenildiği kadar etkin olmasına yol açmaktadır. Bu sorunlara dikkat çeken Ekonomik Kalkınma ve İşbirliği Örgütü (OECD), kendi bünyesindeki Kalkınma Yardımları Komitesini (DAC) destekleyerek kalkınma işbirliği için uluslararası ilke ve standartların özellikle de Binyıl Kalkınma Hedeflerinin takipçisi olduğunu belirtmektedir (OECD, 2019).

Buna yönelik olarak OECD Kalkınma İşbirliği Direktörlüğü tarafından 2003'te Roma'da, 2005'te Paris'te, 2008'de Accra'da ve 2011'de Busan'da gerçekleştirilen Yüksek Düzey Yardım Etkinliği Forumları, kalkınma gündemine yön veren dört önemli etkinlik olarak dikkat çekmektedir (OECD, 2018a). Bu üst düzey etkinlikler ile yardımların etkisini en üst düzeye çıkarmak amaçlamaktadır. 2005 yılında imzalanan Paris Deklarasyonu, kalkınma sürecinde STK'ları kısmen dışta tuttuğu ve sadece hükümetler arası ortaklıkla sınırlı dar bir odağı olduğu gerekçesiyle eleştirilmiştir. 2008 Accra 3. Yüksek Düzey Yardım Etkinliği Forumunda hükümetler, kalkınmaya katkının maksimum

1 Birleşmiş Milletler Binyıl Kalkınma Hedefleri:

1. Aşırı yoksulluğu ve açlığı ortadan kaldırmak

2. Herkes için evrensel ilköğretim sağlamak

3. Cinsiyet Esşitliği ve kadının güçlendirilmesi

4. Cocuk ölümlerini azaltmak

5. Ảnne sağlığını iyileştirmek

6. HIV/AIDS, sıtma ve diğer hastalıklarla mücadele

7. Çevresel sürdürülebilirligği sağlama

8. Kaalkınma için küresel bir ortaklık kurmak 
düzeye çlkarılabileceği bir ortam sağlamak için STK'larla birlikte çalışacaklarını taahhüt etmişlerdir (CONCORD, 2011:3). 2011'de Busan'da gerçekleştirilen 4. Yüksek Düzey Yardım Etkinliği Forumu ise özellikle yardım etkinliği gündeminin değişerek kalkınma gündeminin öne çıkması bakımından dönüm noktası niteliğindedir. Forumun ana ve yan gündemleri, sonuç belgesinde mutabakata varılan ilkeler ve verilen taahhütler söz konusu forumun yardım konulu değil kalkınma konulu olduğunu göstermektedir. Busan'da OECD'nin multi-disipliner uzmanlığa dayanan ve yardımın ötesinde kapsamlı bir kalkınmayı hedefleyen stratejisi hakkında istişarede bulunulmuştur. Yaklaşık 3.000 delegenin katılımıyla gerçekleştirilen forumda, 100'den fazla gelişmiş ve gelişmekte olan ülkenin onayıyla Busan Ortaklık Anlaşması imzalanmış ve etkili yardıma yönelik ilkeler ortaya koyulmuştur. Ortaklık Anlaşması, OECD Kalkınma Yardımı Komitesi (DAC)'nin ev sahipliği yaptığı Yardım Etkinliği Çalışma Grubunun liderliğinde kapsamlı bir müzakere süreci ile desteklenmiştir (OECD, 2018b). OECD, Paris Deklarasyonunu imzalayan birçok ülkenin ve kurumun Ortaklık Anlaşmasından sonra kalkınma etkinliklerini gözden geçirmeleri gerektiğine ve artık odak noktasının yalnızca yardım faaliyeti olmadığa dikkat çekmiştir (Kindornay, 2011:5).

Ortaklık Anlaşmasının yanı sıra yardımların neden istenilen kalkınma sonuçlarını üretemediğini anlamak, Binyıl Kalkınma Hedefleri (MDGs) tarafından belirlenen iddialı hedefleri gerçekleştirmek ve kalkınma için maksimum etki yaratacak finansman, zaman ve bilgiyi sağlanmak amaciyla Etkin Kalkınma İşbirliği Küresel Ortaklığı (GPEDC) kurulmuştur (OECD, 2018a; TRIALOG, 2013:2). OECD Kalkınma İşbirliği Direktörlüğü tarafından hayata geçirilen bu ortaklık ile amaçlanan tüm aktörlerle birlikte çalışarak kalkınmada etkinliği en üst düzeye çıkarmaktır.

Tüm bu gelişmelerin yanı sıra STK'lar hem kendi kurumsal etkinliklerini hem de kalkınmadaki etkinliklerini üst düzeye çıkarmak için müstakil girişimlerde bulunmuşlardır. Kalkınma aktörü olarak küresel ortaklıkta etkinliklerini arttırmak isteyen STK'lar kendilerine rehberlik edecek standartları oluşturmak adına STK Kalkınma Etkinliği Açık Forumunu oluşturmuşlardır. $\mathrm{Bu}$ forum her bir STK'nın kendi etkinliğini geliştirmesi için gerekli araçlara, kaynaklara, örnek olay incelemelerine ulaşabileceği, fikir alışverişinde bulunabileceği açık erişimli bir web portalıdır. Forumun amacı öncelikle STK'ların kendi iç faaliyetlerini şeffaf biçimde sürdürmeleri ve devamlı bir organizasyon sergilemeleridir.

Küresel ortaklığa yönelik olarak dünya genelinde binlerce STK, STK'ların kalkınmada üstlenecekleri rol için kapsamlı bir istişare sürecine dâhil 
olmaktadır. Bu istişare süreci ile beraber küresel sivil toplumun kalkınmadaki çalışmalarının etkinliği hakkında ortak bir bildiri olan "STK Kalkınma Etkinliği Uluslararası Çerçevesi” ortaya çıkmıştır. Söz konusu uluslararası çerçeve kapsamında 2010 Eylül ayında İstanbul'da 82 ülkeden 170'den fazla STK temsilcisi toplanarak İstanbul İlkeleri olarak bilinen ve sivil toplum için uygun bir ortama yönelik minimum kriterleri içeren sekiz ilke oy birliği ile kabul edilmiştir (TRIALOG, 2013:3).

Tam adı ‘İstanbul STK Kalkınma Etkinliği İlkeleri’ olan ilkeler aşağıdaki gibidir:

i. Insan haklarına ve sosyal adalete saygı göstermek ve teşvik etmek

ii. Kadın ve kız haklarını teşvik ederken toplumsal cinsiyet eşitliğini ve adaletini somutlaştırmak

iii. Halkın yetkilendirilmesine, demokratik sahiplenmeye ve katılıma odaklanmak

iv. Çevresel sürdürülebilirliği teşvik etmek

v. Şeffaflığı ve hesap verebilirliği uygulamak

vi. Adil ortaklıkların ve dayanışmanın takipçisi olmak

vii. Bilgiyi ortaya çıkarmak, paylaşmak ve karşılıklı öğrenme taahhüdü vermek

viii. Olumlu sürdürülebilir değişimin gerçekleşmesi için kararlı olmak

Katılım gösteren binlerce STK'nın kapsamlı bir fikir alışverişinde bulunduğu bu açı forum sonucunda ortaya çıkan ilkeler, dünya genelinde STK'ların etkin kalkınma gündemi içindeki rolünü tanımlayan ve strateji geliştirme davranışlarını yönlendiren temel prensiplerdir. Resmi olarak onaylanan ve küresel meşruiyet kazanan ilkeler, STK'ların kalkınma eylemlerindeki görev ve yaklaşımlarındaki çeşitliliği göz önüne almaktadır. Dolayısıyla, yerel bağlam ya da sektör fark etmeden uygulamada rehberlik etmesi amaciyla hazırlanmıştır. STK'ların İstanbul İlkelerini uygulamaya geçirmeleri ve buna yönelik ilerleme kaydetmeleri, büyük oranda bu ilkelerle tutarlı hükümet politikaları, kanunlar ve yönetmeliklere mümkün olacaktır. Söz konusu ilişki, etkin kalkınma sürecinde işbirliğinin ne derece önemli olduğunu bir kez daha göstermektedir (CONCORD, 2011:2). Etkin kalkınma için düzenleyici mekanizmalar arasındaki uyuma işaret eden bu durum iyi yönetişim önermesini destekler niteliktedir.

Etkin kalkınmada rol oynayan tüm aktörlerin hesap verebilirliğini güçlendirmek, paydaşların etkisini ve niteliğini arttırmayı amaçlamak daha gerçekçi, sonuç odaklı ve kapsayıcı yaklaşımları ortaya çıkarmıştır. Uluslararası kalkınma işbirliğindeki son gelişmeler ve ilerlemeler gözden geçirildiğinde 
çeşitli aktörlerin koordinasyonunun teşvik edildiği görülmektedir. İşbirliğindeki rolü bakımından STK'ların daha fazla kapasite sağlaması ve gelişim süreçlerine halkın daha fazla katılımını sağlaması öne çıkan unsurlar olarak dikkat çekmektedir (UN, 2016:4-6).

\section{Sonuç}

Kalkınma yazınındaki hâkim görüş 1950'lerden bu yana pek çok kez değişime uğramıştır. Devletin öncülüğünü vurgulayan geleneksel kalkınma yaklaşımları ile arzulanan sonuçların elde edilememesi sonucunda piyasalara yönelim söz konusu olmuştur. Neoliberal görüşün etkili olduğu 1980'lerde devletin geri çekilmesi ve tam rekabetçi piyasaların teşvik edilmesi önerilmiştir. Ancak küresel serbest piyasa düzenini öngören Washington Mutabakatı'nın da başarıya ulaşamaması hatta küresel yoksulluğu ve eşitsizliği arttırması yeni arayışlara yol açmıştır. Kurumsal başarısızlıkların piyasaların işleyişini olumsuz etkilediğinin görülmesi üzerine Washington Mutabakatı yerini kurumların önemine dikkat çeken Post-Washington Mutabakatı'na bırakmıştır. Alternatif organizasyon araçlarının etkinliğini sağlayan bir koordinasyon biçimi olan yönetişim kavramı yükselişe geçmiştir. Bu doğrultuda tek yönlü kalkınma yaklaşımları terk edilmiş ve tüm paydaşları kapsayan çoğulcu yaklaşımlar öne çıkmıştır.

İyi yönetişimin ancak toplumsal örgütlenmenin kuvvetli olması durumunda başarıya ulaşacağı genel kabul görmektedir. Koordine edici devlet ve kolektif eylemleri gerçekleştiren sivil toplum başarılı kalkınmada önemli unsurlar olarak dikkat çekmektedir. Güçlü bir toplumsal örgütlenme etkinlik, şeffaflık ve hesap verebilirlik gibi yönetişim unsurlarının temelini oluşturmakta ve devamlılığını sağlamaktadır. Yönetişim bakımından ilerleme dolaylı yoldan kalkınma anlamına gelmektedir. Gelişmiş bir yönetişimi tesis etmenin güçlüğü bunun en önemli göstergesidir. Güçlü sivil toplum iyi yönetişime, iyi yönetişim de etkin kalkınmaya katkı sağlamaktadır. Sivil toplumun kurumsal temsilcileri olan STK'lar, piyasa ve devletin düzenleyici mekanizmalarının yanında yer alarak katılımcı demokrasiyi ve kalkınmayı güçlendirmektedirler.

Bu çalışmada STK'lar birer yönetişim mekanizması olarak ele alınmış ve özellikle 1990 sonrasında uluslararası kurum ve kuruluşların önderliğinde STK'ların kalkınmadaki yeri tartışılmıştır. Uluslararası etkin kalkınma, işbirliği ile güçlenmektedir. Yönetişimin ayrılmaz bir parçası olan STK'lar, strateji geliştirme davranışlarını zaman içinde değiştirmeleri durumda uluslararası kalkınma işbirliğinde önemli bir ortak olarak yer almaktadırlar. Ayrıca 
etkin kalkınma adına oluşturulan uluslararası ilke ve standartların belirlenmesinde aktif bir rol oynamaktadırlar. Dünya Bankası, IMF ve OECD gibi öncü uluslararası kurumlarla yapılan ortaklıklar, tüm aktörlerle birlikte çalışarak kalkınmada etkinliği en üst düzeye çıkarmayı amaçlamaktadır. Bu noktada STK'ların üstlendikleri rol oldukça önemlidir.

\section{Kaynakça}

Aysan, Ahmet F. (2019), "Yönetişim ve Kurumlar Terimlerinin İktisat Literatüründe Yükselişi” http://www.econ.boun.edu.tr/content/wp/ISS_EC_06_16.pdf (E.T. 14.05.2019).

Bardhan, Pranab (1993), "Economics of Development and the Development of Economics", The Journal Of Economic Perspectives, 7 (2), ss.129-142.

Bayramoğlu, Sonay (2005), Yönetişim Zihniyeti: Türkiye’de Üst Kurullar ve Siyasal Iktidarın Dönüşümü, İstanbul: İletişim.

Brett, Edward.A. (1993), "Voluntary Agencies as Development Organizations: Theorizing the Problem of Efficiency and Accountability", Development and Change, Vol. 24, ss.269303.

Cameron, John (2000), "Development Economics, the New Institutional Economics and NGOs”, Third World Quarterly, Vol. 21, No. 4, NGO Futures: Beyond Aid, ss.627-635.

Commins, Stephen (1999), “NGO's: Ladles in the Soup Kitchen?”, Development in Practice, 9 (5), ss.619-622.

CONCORD (2011), The Siem Reap CSO Consensus on The International Framework For CSO Development Effectiveness. Agreed By The Second Global Assembly, Open Forum For Cso Development Effectıveness, Siem, Reap, Cambodıa, June 28 - 29, 2011, https:// acfid.asn.au/sites/site.acfid/files/resource_document/The_Siem_Reap_CSO_Consensus.pdf (E.T. 17.07.2019).

Dagher, Ruby (2017), “Civil society and development: a reconceptualisation”, Canadian Journal of Development Studies / Revue canadienne d'études du développement, Vol.38 No.1, ss.54-71.

Edwards, Michael; Hulme, David ve Wallace, Tina (1999), "NGOs in a global future: marrying local delivery to worldwide leverage”, Public Administration and Development, Vol.19,ss. 117-136.

Etzioni, Amitai (1973), "The Third Sector and Domestic Missions", Public Administration Review, Vol. 33, No. 4 (Jul. - Aug., 1973), ss.314-323.

Fowler, Alan (2000), Civil Society, Ngdos And Social Development: Changing The Rules Of The Game. Cenevre 2000 Occasional Paper, No.1. United Nations Research Institute for Social Development, file://C:/Users/CASPER/Downloads/Civil_Society_NGDOs_and_Social_Development_Changin.pdf (E.T. 17.07.2019).

Jessop, Bob (1998), "The Rise of Governance and The Risk of Failure: The Case of Economic Development”, International Social Science Journal, Vol. 50, Issue: 155, March 1998, ss.29-45.

Keyman, Fuat (2004), Türkiye'de ve Avrupa'da Sivil Toplum. Sivil Toplum ve Demokrasi Konferans Yazıları, İstanbul Bilgi Üniversitesi, İstanbul, No: 3, 1-34, https://stk.bilgi.edu.tr/ 
media/uploads/2015/02/01/keyman_std_3.pdf (E.T. 17.07.2019).

Kindornay, Shannon (2011), From Aid to Development Effectiveness: A Working Paper, The North-South Institute, http://www.nsi-ins.ca/wp-content/uploads/2012/10/2011-From-aid-to-development-effectiveness.pdf(E.T. 17.07.2019).

Kontinen, Tiina ve Millstein, Ira M. (2017), "Rethinking Civil Society in Development: Scales and Situated Hegemonies”, Forum for Development Studies, 2017 Vol. 44, No. 1, ss.69-89.

Korten, David C. (2009), Agenda For A New Economy: From Phantom Wealth To Real Wealth, San Francisco: Berrett-Koehler Publishers.

Levent, Adem (2016), “Yönetişim ve Yeni Kurumsal İktisat”, iktisat Politikası Araştırmaları Dergisi, 3 (2), ss.17-32.

Lewis, Davis ve Kanji, Nazneen (2009), Non-Governmental Organizations and Development, Routledge Perspectives on Development, London: Routledge.

Lyon, Patricia (2000), "Partnership for Good Governance in the 21st Century", Australian Journal of Public Administration, 59 (3), ss.87-93.

Malhotra, Kamal (2000), “NGOs without aid: Beyond the Global Soup Kitchen”, Third World Quarterly, 21:4, ss.655-668.

North, Douglass. C. (2002), Kurumlar, Kurumsal Değişim ve Ekonomik Performans, (çev:Gül Ç. Güven), İstanbul: Sabancı Üniversitesi.

OECD (2018a), http://www.oecd.org/dac/effectiveness/thehighlevelforaonaideffectivenessahistory.htm (E.T. 17.07.2019).

OECD (2018b), http://www.oecd.org/dac/effectiveness/oecdandthefourthhighlevelforumonaideffectiveness.htm (E.T. 17.07.2019).

OECD (2019), https://www.oecd.org/dac/ (E.T. 17.07.2019).

Pearce, Jenny (2000), “Development, NGOs, and civil society: the debate and its future”. Deborah Eade (ed.), Development, NGOs, and Civil Society, Oxfam GB, Oxford, OX4 2JY, UK.

Psacharopoulos, G. ve Nguyen, X. (1997), The Role of Government and The Private Sector in Fighting Poverty, Technical Paper, No.346, World Bank, Washington DC.

Rodrik, Dani (2008), "Thinking about Governance", Governance, Growth, and Development Decision-making, The International Bank for Reconstruction and Development/ The World Bank

Salamon, Lester M. ve Anheier, Helmut K. (1992), "In search of the non-profit sector.l: The question of definitions", Voluntas: International Journal of Voluntary and Nonprofit Organizations, November 1992, 3 (2), ss.125-151.

Salamon, Lester M. ve Anheier, Helmut K. (1999), "Civil Society in Comparative Perspective” L. M. Salamon, H. K. Anheier, R. List, S. Toepler, S. W. Sokolowski (Ed.) Global Civil Society: Dimensions of the Nonprofit Sector, The Johns Hopkins Center for Civil Society Studies, Baltimore, ss.3-40.

Sarıbay, A. Yaşar (2013), Demokrasinin Sosyolojisi. İstanbul: Sentez.

Sarıbay, A. Yaşar (2014), Postmodernite Sivil Toplum ve İslam. İstanbul: Sentez.

Savran, Gülnur (1984), "Sivil Toplumun Eleştirisi”, Yapıt Dergisi, s.5.

Scholte, J. Aart (2002), "Civil Society and Democracy in Global Governance", Global Governance, Vol.8, No.3, ss.281-304. 
Sobacı, M. Zahid (2007), "Yönetişim Kavramı Ve Türkiye'de Uygulanabilirliği Üzerine Değerlendirmeler", Yönetim Bilimleri Dergisi, 5(1), ss.219-235.

Stiglitz, Joseph (2013), “Küreselleşen Dünya’da Kalkınma Politikaları”, Fikret Şenses (ed.), Neoliberal Küreselleşme ve Kalkınma-Seçme Yazılar, İstanbul: İletişim, ss.281-306.

Teegen, Hildy; Doh, P. Jonathan ve Vachani, Sushil (2004), “The İmportance of Nongovermental Organizations (Ngos) in Global Governance and Value Creation: An International Business Research Agenda”, Journal of International Business Studies, 35, ss.463-483.

Trialog (2013), Development Effectiveness \& the Role of Civil Society Organisations. Policy Digest, No:6, December.

Tuijl, V. Peter (2000), “Entering The Global Dealing Room: Reflections on A Rights-Based Framework For Ngos in İnternational Development.", Third World Quarterly, 21 (4), ss.617-626.

UN (2016), United Nations Economic and Social Council, https://www.un.org/ecosoc/en/ node/310191 (E.T. 13.11.2016).

Veltmeyer, Henry (2006), Latin Amerika ve Başka Kalkınma. Özkan Akpınar (çev.), İstanbul: Kalkedon.

Wayenberge Van, E. (2013), “Washington Mutabakatı'ndan Washington Sonrası Mutabakata: Kalkınma Yanılsamaları” Fikret Şenses (ed.), Neoliberal Küreselleşme Ve Kalkınma-Seçme Yazılar, İstanbul: İletişim, ss.307-345.

Williamson, Oliver E. (1985), The Economic Institutions of Capitalism: Firms, Markets, Relational Contracting. New York: Free Press.

Williamson, Oliver E. (1996), The Mechanisms of Governance, Oxford University Press.

World Bank (1998), http://documents.worldbank.org/curated/en/390771468320070967/pdf/ multi-page.pdf (E.T. 06.11.2017).World Bank (2013),

http://web.worldbank.org/WBSITE/EXTERNAL/TOPICS/CSO/0,,contentMDK:20101499 menuPK:244752 pagePK:220503 piPK:220476 theSitePK:228717,00.html (E.T. 06.11.2017).

World Bank (2017), http://www.worldbank.org/en/events/2017/04/21/civil-society-policy-forum. (E.T. 06.11.2017).

Yüksel, Esra (2014), “Kalkınma ve Sivil Toplum”, Ahmet F. Aysan, Devrim Dumludağ (ed.), Kalkınmada Yeni Yaklaşımlar, Ankara: İmge, ss.147-170. 